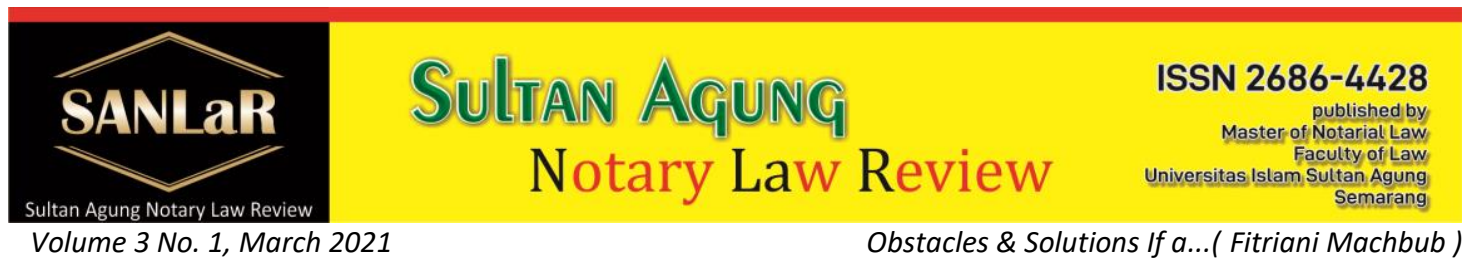

\title{
Obstacles \& Solutions If A Legal Agency Administration System in Process of Restruction of A Limited Company
}

\author{
Fitriani Machbub $\left.{ }^{*}\right)$, Akhmad Khisni ${ }^{* *}$ and Amin Purnawan ${ }^{* * *}$ \\ *) Student of Master of Notary Law, Faculty of Law, Universitas Islam Sultan \\ Agung (UNISSULA) Semarang \\ $\left.{ }^{* *}\right)$ Lecturer of Master of Notary Law, Faculty of Law, Universitas Islam Sultan \\ Agung (UNISSULA) Semarang \\ $\left.{ }^{* * *}\right)$ Lecturer of Master of Notary Law, Faculty of Law, Universitas Islam Sultan \\ Agung (UNISSULA) Semarang
}

\begin{abstract}
The purpose of this study is to explain how the obstacles and solutions if they occur in the legal entity administrative system in the Limited Liability Company approval process. This writing uses the juridical empirical research method by extracting information from interviews and data from literature studies. The data used in this study are secondary data which includes primary legal materials. Based on this research, it can be concluded that the Registration of Limited Liability Companies using the Legal Entity Administration System has obstacles and has disadvantages for its users, one of which is the website system itself, where the pages on the website are off or busy with the network, so the process will take a long time until hours due to slow access.
\end{abstract}

Keywords: Barriers; Solution; Legal Entity Administration System; Limited company.

\section{Introduction}

Based on Article 1 number 1 of Act No 40 of 2007 concerning Limited Liability Companies, is a Legal Entity which is a Capital Alliance, established based on an agreement, conducting business activities with authorized capital which is entirely divided into shares and fulfills the requirements stipulated in the law and its implementing regulations. Limited Liability Companies are legal subjects who have the right to become holders of rights and obligations, including being the owner of certain objects or assets.

Limited Liability Company is a legal entity, which means that it can bind itself and carry out legal actions like an individual and can have assets or debts. There is wealth separate from the personal wealth of each company with the aim of forming a number of funds as collateral for all corporate engagements.

Legal Entity Administration System or abbreviated as SABH is the Company's Information Technology Services as well as electronically organized by the Directorate General of General Legal Administration. To the public by using a 
computerized system in processing applications for ratification of the deed of establishment and applications for approval of Amendments to the Articles of Association of Limited Liability Companies which are conducted online. Applications for Legal Entity for the Company are submitted through SABH, namely on the AHU Online website at the addresshttps://www.ahu.go.id.

The application of the Legal Entity Administration System in granting legal entities for Limited Liability Companies that utilize advanced technology using the internet network to provide Legal Services in the field of Legal Entity Companies so that services to the public can be carried out quickly and on time.

The ratification of a Limited Liability Company using the Legal Entity Administration System has obstacles to its use even though it is not only practical, but also faster, efficient, economical, and can minimize or avoid the occurrence of acts or actions such as collusion or clay levies

Broadly speaking, the constraints or obstacles that arise in the Legalization of the Establishment of a Limited Liability Company can be overcome by the existence of an electronic Legal Entity Administration System (SABH), such as the problem of time and efficiency in monitoring the right to this process.

\section{Research Methods}

The research method used is the Empirical Juridical Research Method, The juridical empirical approach is carried out with field research aimed at the application of Act No 40 of 2007 and the AHU-Online System. The Juridical Empirical approach is carried out by looking at the realities that exist in practice in the field. This approach is also known as the sociological approach which is carried out directly in the field.

\section{Results and Discussion}

What are the obstacles and solutions if they occur in the Legal Entity Administration System (SABH) in the Limited Liability Company (PT) Approval Process?

The obstacles that occur in the legalization of Limited Liability Companies both in the old system and the new system include:

1. Technical Barriers

a. Old System

1) In the old system where the whole process was done manually, there was often a problem of delays, this was because the officers had to check the incoming requests one by one, while the number of incoming requests was far more than the capacity of the existing officers. The risk of human error occurring is quite large because each data must be matched against a large number of documents. 
2) For Notaries, the old system will make the process inefficient because they have to check with the Department of Law and Human Rights in Jakarta, this is because the whole process can only be carried out and monitored in Jakarta.

3) Tracing the ongoing process is difficult because there is no online system that can monitor the manufacturing process.

4) The process of ratifying the deed of establishment of a Limited Liability Company is carried out manually based on the provisions in the Decree of the Minister of Justice Number M.01-PR.08.01 Year 1996, based on experience so far, it is difficult to complete it on time in accordance with the provisions in Article 9 paragraph (2) of the Act No. 1 of 1995 (UUPT), which is within 60 (sixty) days after the application is received. The obstacles that occur include:

a. The number of requests that came in every day was enormous.

b. The complexity or the number of elements of the application requirements that must be corrected manually by the officers is relatively unbalanced compared to the number of applications received.

b. New System

1) Notaries who are in the area certainly have difficulty accessing the internet, because in every region in Indonesia it has reached internet technology.

2) The existence of the Human Resources factor, which comes from the Notary itself, namely the natural ability to operate the Internet and human errors from the Notary who incorrectly enter data.

3) Data breaches are prone to occur, especially by hackers, who are cyber criminals.

2. Administrative Barriers

a. Old System (none)

b. New System

The cost of access to SISMINBAKUM (access fee) is relatively more expensive when compared to the old system (manual).

3. Juridical Barriers

a. Old System (none)

b. New System

With regard to internet users, the Law in Indonesia has not accommodated many problems related to the use of interners, particularly regarding cybercrime in the Notariat sector.

From the results of the interview it can be concluded that the registration of Limited Liability Companies using the online system (SABH) has obstacles and has 
deficiencies in its use, even though it is not only practical, but also faster and more efficient, effective, economical, transparent and can minimize or prevent actions or actions such as committing collusion. Or extortion fees.

Solutions to overcome the Barriers in Limited Liability Company Ratification, namely:

1. Manually

Broadly speaking, the constraints and obstacles that arise from the manual system in ratifying the establishment of a Limited Liability Company can be overcome by the existence of an electronic Legal Entity Administration System $(\mathrm{SABH})$, such as the problem of time and efficiency in monitoring the right to this process.

2. Electronically via SABH

a. Regarding the relatively more expensive cost, the only effort the notary can do is to provide an understanding with the manual system. And it is better to make an agreement regarding the stages of payment by the client, because in the Legal Entity Administration System, each stage has its own rate that must be paid to be able to proceed to the next stage, there is this agreement to avoid clients with bad intentions.

b. For notaries who are in certain areas who have difficulty accessing intern, because not every region in Indonesia has reached internet technology, all that can be done is to submit a request to continue to legalize the establishment of a PT manually.

c. Regarding the Human Resources factor, in this case, trainings on SABH and the Internet can be carried out, in fact there have been similar trainings, but often this is not effective for old Notaries, for example, preferring to be represented by other people or in this case the employees who are in the office environment, so that the understanding of the cyber world and its relation to SABH is not deep, this is important because technology besides having a positive impact also has a negative impact that always follows it. This ineffectiveness is also seen in training management, and for areas such as districts outside Java, for example, it seems that they have not yet fully covered this training.

d. With regard to data encroachment, especially by Hackers, who are perpetrators of cyber crimes, it is better if the Notary logs in to SABH access, the concept of password confidentiality itself must be considered and also do not necessarily close the access view just like that, without logging out to protect it. The occurrence of data breaches and the use of access by others.

Legal issues that arise in the Ratification of Limited Liability Companies on SABH through AHU-Online: 
The process of ratification of the Company's Legal Entity in SABH through an internet facility is carried out by a Notary where the Notary simply accesses the SABH Application Program through AHU Online in order to carry out the Company Registration Process to become a Legal Entity which can cause various legal problems. Legal issues that can arise in this process, such as legal requirements that must be met in the process of legalization of legal entities electronically, the fulfillment of the Accuracy and Validation factors as well as legal requirements in every form of company data input, and also include problems of legal settlement and protection if they occur. Disputes in the process of Ratification of the Company's Legal Entity through the SABH.

In electronic transactions such as in $\mathrm{SABH}$, it is very difficult to determine a person who makes a transaction and declares himself a notary whether the person is capable of conducting an engagement, because the application process that occurs is not directly carried out, but through internet media that cannot be seen by the person making the transaction. The. If it is proven that the person who made the transaction is not legally competent to carry out a transaction, the agreement may be canceled.

The agreement is declared valid if it fulfills the 4 (four) conditions stipulated in Article 1320 of the Civil Code, namely the agreement that those who bind themselves are competent to make an engagement, a certain thing and a lawful cause. In terms of the validity of the agreement, the ability to make an engagement, except under the law, are those who are not yet mature and those who are under interdiction.

Barriers and Solutions if they occur in the AHU Online System in the Limited Liability Company Approval Process, if it is proven that the person who carried out the transaction is not legally competent to carry out a transaction, then the agreement may be canceled if there is a violation of the contents of the agreement of establishment of a company, several legal actions may be taken. violation of the terms of the agreement due to an error, coercion or fraud and competency requirements, then the legal action that can be taken is canceling the agreement of establishment of the company, this cancellation is carried out by the judge at the request of the founder or a person who according to the law is not legally competent or not, or it can also be by a founder who according to the law is declared legally competent and is permitted to express incompetence. Founders who are not legally competent or not as regulated in Article 1331 of the Civil Code. whereas if there is a violation of the conditions of a certain matter, as well as a violation of the conditions of a lawful cause, then the agreement of establishment of the company is null and void, meaning that from the beginning it is assumed that there has never been an agreement or has never been born an agreement or engagement regarding the establishment of the company. 


\section{Closing}

Registration of Limited Liability Companies using the Online System or SABH has obstacles and has disadvantages for its users, even though it is not only practical, but also faster and efficient, effective, economical, transparent and can minimize or prevent the occurrence of actions or actions such as collusion or illegal levies.

The obstacles that occur are:

a. Regarding the website system itself, which is where the page on the website is off or busy with the network. This is what causes obstacles to the process of legalizing the Limited Liability Company legal entity. When the network is busy, the process may take up to hours due to slow access.

b. Regarding the Notary's client, the most frequent obstacle in the process of legalizing the establishment of a Limited Liability Company is that the client who has bad intentions by falsifying the data brought to the Notary concerned, dishonesty of the Notary's client which can cause obstacles for the Notary in validating the company's legal entity.

\section{References}

Journals:

Ridwan Khairandy. (2007). Perseroan Terbatas Sebagai Badan Hukum, Jurnal Hukum Bisnis, Volume 26, No.3

Books:

[1] Ginting, Jamin. (2007). Hukum Perseroan Terbatas (UU No. 40 Tahun 2007), Bandung : PT. Citra Aditya Bakti

[2] Dwi Hariyani, R. Serfianto Dibyo Purnomo dan Cita Yustisia Serfiyani, Panduan Praktis SABH Sistem Administrasi Badan Hukum, Yogyakarta, Pustaka Yustisia, Cetakan Pertama, 2011

Regulation:

[1] Act No 1 of 1995 (UUPT)

[2] Act No 40 of 2007 concerning Limited Liability Companies

[3] Code of Civil law 